\title{
Effect of Heavy Metals and Nutrients Levels of Ballast Waters in Commercial Ships on Chemical Quality Status of Seawater of the Tobruk-libya Gulf
}

\author{
Gaith Gaballa Altohame Jalgaif ${ }^{1}$, Salah Ali Mahgoub Idris ${ }^{2,}$, , Rabie Ali Maarouf ${ }^{3}$, \\ Ahmed Moursy Attia ${ }^{4}$, Manal Mahmoud El-Naggar ${ }^{5}$ \\ ${ }^{1}$ Port \& Maritime Transport Authortity, Ministry of Transport, Tobruk, Libya \\ ${ }^{2}$ Chemistry Department, Faculty of Science, Tobruk University, Tobruk, Libya \\ ${ }^{3}$ Oceanography Department, Faculty of Science, University of Alexandria, Alexandria, Egypt \\ ${ }^{4}$ Department of Environmental Studies, Institute of Graduate Studies and Research, University of Alexandria, Alexandria, Egypt \\ ${ }^{5}$ Marine Environmental Division, National Institute of Oceanography and Fisheries, Alexandria, Ministry of Scientific Research, Alexandria, \\ Egypt
}

Email address:

salah.idris@ymail.com (S. A. M. Idris)

${ }^{*}$ Corresponding author

\section{To cite this article:}

Gaith Gaballa Altohame Jalgaif, Salah Ali Mahgoub Idris, Rabie Ali Maarouf, Ahmed Moursy Attia, Manal Mahmoud El-Naggar. Effect of Heavy Metals and Nutrients Levels of Ballast Waters in Commercial Ships on Chemical Quality Status of Seawater of the Tobruk-libya Gulf. American Journal of Environmental and Resource Economics. Vol. 4, No. 4, 2019, pp. 121-124. doi: 10.11648/j.ajere.20190404.11

Received: August 15, 2019; Accepted: September 16, 2019; Published: October 9, 2019

\begin{abstract}
Marine transportation still generates negative impacts on the marine environment, including releases of ballast water containing aquatic invasive species; historical use of antifoulants; oil and chemical spills; dry bulk cargo releases; garbage; underwater noise pollution; ship-strikes on marine megafauna; risk of ship grounding or sinkings; and widespread sediment contamination of ports during trans-shipment or ship breaking activities. Commercial vessels that do not conduct ballast water exchange, in accordance with International Convention Ballast Water Management, will endager the environment of ports. In this study, investigation of heavy metal $(\mathrm{Cd}, \mathrm{Cu}, \mathrm{Fe}, \mathrm{Mn}, \mathrm{Pb}$ and $\mathrm{Zn})$ and nutrients $\left(\mathrm{NO}_{3}, \mathrm{NO}_{2}, \mathrm{NH}_{4}, \mathrm{PO}_{4}\right.$ and $\left.\mathrm{SiO}_{4}\right)$ contents in ballast waters of three commercial ships entering the Tobruk port, along the Tobruk Gulf. High concentration levels were observed in all samples which were the main source of high heavey metals concentration of coastal waters of Tobruk Gulf. These results were confirmed by determination of nutrients concentration which were also found in high concentrations levels compared with reference sample. Results showed that in a long term the ballast water has the potential to change the chemical quality in marine environments, and it should treated before discharge in coastal areas, as well as the unpolluted of ballast waters should be loaded.
\end{abstract}

Keywords: Ballast Water, Heavy Metals, Nutrients, Tobruk Gulf

\section{Introduction}

International Maritime Organization (IMO) is a United Nations organization that attempts to increase the safety of shipping and protection of marine environment. One of of comittees in the organization is the Commitee of Marine Environment Protection (MEPC) in 2004 that has legalized regulations of controlling management of vessel ballast water. The regulation of ballast water set by IMO which aims to minimalize the entrance of indigenous species and sediments to other water areas. To minimalize the risk, based on D1 standards, each commercial vessel entering to port water areas is requested to do ballast water exchange in ballast water tank that is located 200 miles from the port, in depth of more than 200 meters, and by level of efficiency of at least $95 \%$. There are three methods used in ballast water exchange. First, sequential method, a process of emptying and refilling ballast water to get at least $95 \%$ of volumetric 
exchange. Second, flow-through method, a process of pumped ballast water exchange so that the water comes through overflow pipes or other structures. Third, dilution method, a process of ballast water exchange that is filled through the upper parts of ballast water tank by simultaneous release from bottom of the tank [1].

Changes in the physico-chemical parameters in coastal waters have been attributed to human activities but little is known about how much is contributed by ballast water being discharged by ships all over the world on a daily basis [2-4]. Industrial and urban wastewater, power plants, sea traffic and ballast water disposals related to port services are the main sources of heavy metals and nutrients in coastal environments. Heavy metals were discharged into the marine environment and potentially accumulated, which can negatively affect humans and marine ecosystems health [5]. Some of heavy metals are toxic even at low concentration level. The existence of heavy metals at a certain elevated concentration in marine environment creates a societal health risk which is harmful for fisheries and human nutrition [6]. Heavy metal pollution in marine organisms has become a serious worldwide concern [7]. Therefore, it needs to be carefully and routinely screened to ensure that there are no high content of heavy metals being transferred to man through sea food consumption $[8,9]$. On the other hand the most important property of sea water in terms of its effect on life in the oceans is the concentration of dissolved nutrients. The most critical of these nutrients are nitrogen and phosphorus because they play a major role in stimulating primary production by plankton in the oceans. However, there are a number of other nutrients that also play a role, including silicon [10]. Many scientists fear that the high nutrients in seawater concentrations have the potential to decrease marine biodiversity on a very large scale [11-13].

In the present study, and as the first study in the region of the Tobruk-Libya Gulf, we aimed to investigate the heavy metal and nutrients contents in ballast waters of three commercial ships entering the Tobruk port, along the Tobruk Gulf.

\section{Sampling and Methods}

Tobruk is a port city on Libya's eastern Mediterranean coast. It is the capital of the Butnan District (formerly Tobruk District) and has a population of 120,000 (2011 est.). The Port of Tobruk is a port located in Eastern Libya near the Egyptian border - about $450 \mathrm{~km}$ east of Benghazi. The Tobruk gulf and adjacent marine environment are under risk of discharged wastewaters from drains, ballast water and oil port located in Tobruk gulf. These pollutants cause dysfunctions in the food web that might lead a total ecosystem imbalance, especially because of the low water exchange rate with the open sea.

Ballast water samples were taken from commercial ships (without any ballast water treatment system) entering Tobruk gulf. Samples were taken from ships comes from 3 different ports around the midille east regoin (see Figure 1).

The water sample is filtered by using $40(0.42 \mu \mathrm{m})$ whatman filter paper and washed by using $\mathrm{HNO}_{3}$ concentrated to $\mathrm{PH}<2$. Then, it is placed in water sample of 51 volume. The water sample is then brought to the laboratory. The water $(100 \mathrm{ml})$ is mixed thoroughly and put in the beaker. Then, it is added by $5 \mathrm{ml}$ of citric acid and heater, $50 \mathrm{ml}$ of distilled water is added, and the mixture is put in $100 \mathrm{ml}$ of graduated flask $[9,10]$. The level of heavy metal $\mathrm{Cd}$ and $\mathrm{Zn}$ in the sample of ballast water of commercial vessel is determined by a Thermo Scientific iCAP 6200 ICP-OES. Nutrients analysis were determined according to Ref. [14].

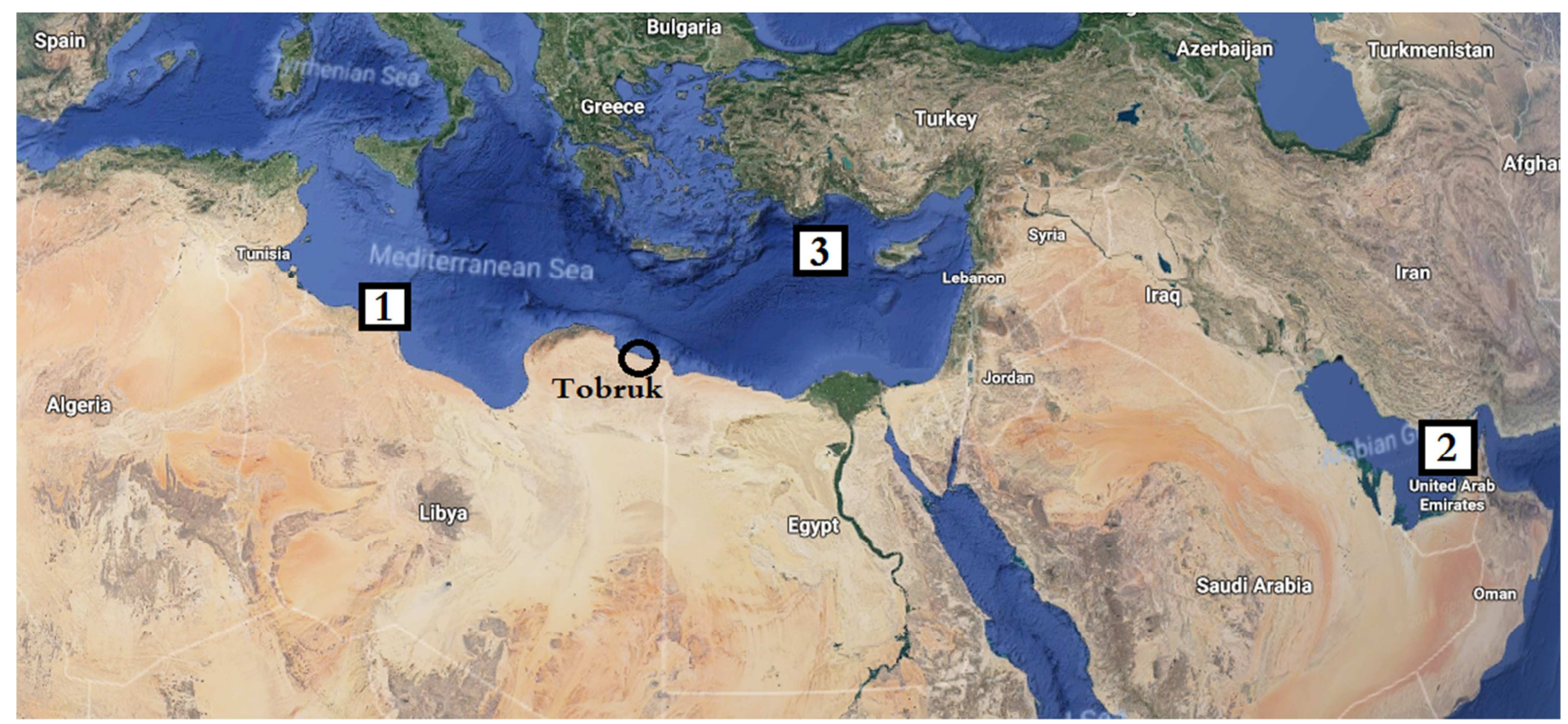

Figure 1. Sources of Ballast water samples were taken from commercial ships: 1. Port of Tripoli-Libya, 2. Port of Fujairah- United Arab Emirates and 3. Port of Isdemir-Turkey. 


\section{Results and Discussions}

Heavy metal is metal with the density of five $\mathrm{gr} \mathrm{cm}^{-3}$ or more. It has atom number from 22 to 96 . The characterictics of heavy metal are, it has bigger gravitational specification (more than 4), it has atom number responds of specific biochemistry on living organism. The source of heavy metal pollutants are from natural and artificial sources. The natural source is from the coastal area (from rivers and coastal abrasion due to wave activity), metal released from volcanoes activity, and chemistry process. The artificial source is from industrial process of mining activity [15].

In this work three different ballast waters with differents three sources (1. Port of Tripoli-Libya (BW1), 2. Port of Fujairah- United Arab Emirates (BW2) and 3. Port of IsdemirTurkey (BW3)) were investigated and the results were compared with sample collected from coastal waters of Tobruk Gulf to study effecting of heavy metals and nutreints levels of ballast waters in commercial ships on chemical quality status of seawater of the Tobruk-Libya Gulf. Estimation of chemical quality status of the Mediterranean Sea and it was affected by ballast water discharge a reference sample from seawater collected from about 1 kilometer in Mediterranean Sea away from of Tobruk Gulf. The concentration levels of heavy metals in the ballast waters are shown in Table 1. The highest concentration levels were observed in BW2 sample and it was big differences with RS sample rsults wich indicate the high pollution levels of ballast water samples. Results of this study indicated also that the concentration levels of coastal waters of Tobruk Gulf has effected by heavy metals of ballast waters discharged from ships under invistagation.

Table 1. Concentration levels $\left(\mu g L^{-1}\right)$ of heavy metals in ballast water samples.

\begin{tabular}{llllll}
\hline Heavy Metals & BW1 & BW2 & BW3 & TG $^{\text {a }}$ & RS $^{\text {b }}$ \\
\hline $\mathrm{Cd}$ & 0.23 & 2.65 & 0.13 & 0.08 & 0.01 \\
$\mathrm{Cu}$ & 13.1 & 57.4 & 20.8 & 10.9 & 2.92 \\
$\mathrm{Fe}$ & 198.2 & 254.9 & 191.2 & 244.4 & 164.8 \\
$\mathrm{Mn}$ & 0.33 & 2.36 & 0.49 & 0.28 & 0.14 \\
$\mathrm{~Pb}$ & 3.31 & 6.97 & 2.91 & 4.66 & 0.21 \\
$\mathrm{Zn}$ & 3.89 & 3.74 & 2.41 & 1.98 & 0.58 \\
\hline
\end{tabular}

${ }^{\mathrm{a}}$ Value of heavy metals concentration in coastal waters of Tobruk Gulf ( $\mu \mathrm{g}$ $\left.\mathrm{L}^{-1}\right)$.

${ }^{b}$ Value of heavy metals concentration in seawater collected from about one kilometer in Mediterranean Sea away from of Tobruk Gulf $\left(\mu \mathrm{g} \mathrm{L}^{-1}\right)$.

These results were confirmed by investigation of nutrients concentration (Table 2). Very high concentrations of netrients in ballast waters samples compared with reference sample and that was the reason for high levels of nutreints concentrations in Tobruk Gulf.

Table 2. Concentration levels ( $m g L^{-1}$ ) of nutrients in ballast water samples.

\begin{tabular}{llllll}
\hline Nutrients & BW1 & BW2 & BW3 & TG & RS \\
\hline $\mathrm{NO}_{3}$ & 2906 & 597.9 & 144.2 & 57.77 & 0.88 \\
$\mathrm{NO}_{2}$ & 0.147 & 5.09 & 48.3 & 23.6 & 0.01 \\
$\mathrm{NH}_{4}$ & 286.9 & 0.214 & 14.85 & 10.93 & 0.074 \\
$\mathrm{PO}_{4}$ & 28.81 & 83.29 & 120.8 & 33.41 & 8.157 \\
$\mathrm{SiO}_{4}$ & 9403 & 2622 & 3933 & 4678 & 145.6 \\
\hline
\end{tabular}

\section{Conclusion}

Marine transportation drives global trade, moving over 10 billion tonnes of containers, solid and liquid bulk cargo across the world's seas annually. Historically, shipping companies and ports operated with limited environmental oversight, but accidental oil spills in the 1960s, caused widespread coastal pollution and seabird mortality, triggering the International Convention for the Prevention of Pollution from Ships (MARPOL). MARPOL is the main international convention to prevent marine pollution by ships from operational or accidental causes. Additionally, the International Maritime Organization (IMO) uses various instruments to protect the marine environment from shipping activities.

The results of the this study presents how the ballast waters discharged by ship tankers in sea can be one of the main sources of metal contamination and high resk can caused by high levels of neuteints in marine environment and may change the chemical quality status of seawater. The pollution caused by ballast waters of ship tankers may adversely affect the marine environment ecosystem. The content of heavy metal in the ballast water vessels shows that the vessels have not conducted ballast water exchange before entering to Tanjung PTES. The more frequency vessels entry and more dead weight, more dangerous the ballast water discharged into the port waters. It will put the marine environment around the port in danger. The clrear messege obtained from this work is to have more attention about ballast waters and treatment before discharge in coastal areas, as well as the quality control of ballast waters before loading in to ship tankers are of highly recommended.

\section{Refereances}

[1] International Maritime Organization 2009 Ballast Water Management Convention and the Guideliness for Its Implementation 2009 Edition (London: International Maritime Organization).

[2] M. David, S. Gollasch, Marine Pollution Bulletin, (2018).

[3] C. Grob, B. G. Pollet, Marine Pollution Bulletin, 109 (2016) 46-48.

[4] X. Zhang, M. Bai, Y. Tian, H. Du, Z. Zhang, Marine Pollution Bulletin, 124 (2017) 89-93.

[5] A. Velusamy, P. Satheesh Kumar, A. Ram, S. Chinnadurai, Marine Pollution Bulletin, 81 (2014) 218-224.

[6] S. Dobaradaran, F. Soleimani, I. Nabipour, R. Saeedi, M. J. Mohammadi, Marine Pollution Bulletin, 126 (2018) 74-76.

[7] F. Fu, Q. Wang, Journal of Environmental Management, 92 (2011) 407-418.

[8] Z. S. Baharom, M. Y. Ishak, Procedia Environmental Sciences, 30 (2015) 320-325.

[9] M. David, S. Gollasch, L. Penko, Journal of Sea Research, 133 (2018) 60-72. 
[10] S. Takeda, Nature, 393 (1998) 774.

[11] S. Badylak, E. J. Phlips, J. of Plank. Res., 26 (2004) 1229-1247.

[12] M. J. Laamanen, J. of Plank. Res., 19 (1997) 1385-1403.

[13] H. G. Marshall, L. Burchardt, R. Lacouture, J. of Plank. Res., 27 (2005) 1083-1102.
[14] K. Grasshoff, K. Kremling, M. Ehrhardt, Methods of Sea Water Analysis, WILEY-VCH Weinheim, New York, 1999.

[15] A. Tjahjono, A. N. Bambang, S. Anggoro, Earth and Environmental Science, 55 (2017) 12-20. 